\title{
Impact of some Organic and Inorganic Amendments on some Soil Properties and Wheat Production under Saline-Sodic Soil
}

Bayoumy, M. A.; T. H. H. Khalifa and H. M. Aboelsoud

Soils, Water and Environment Research Institute, Agricultural Research Center, Egypt

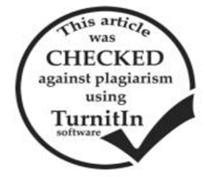

\section{ABSTRACT}

Two field experiments were conducted at two sites in Sakha Agric. Res. Station Farm, North Delta, during two successive winter seasons, 2017/2018 and 2018/2019 to study the effect of individual and combined applications of gypsum, compost tea and biochar on some soil properties and wheat (Triticum aestivum, $L$ ) productivity under saline and saline-sodic soils. Gypsum requirements (G), $400 \mathrm{~L}$ compost tea $(\mathrm{C}), 1 \mathrm{Mg}$ biochar $\left(\mathrm{B}_{1}\right)$ or $2 \mathrm{Mg}$ biochar $\left(\mathrm{B}_{2}\right)$ were applied. Data revealed that application of $\mathrm{G}+\mathrm{C}+\mathrm{B} 2 \mathrm{decreased}$ soil ECe by 28.06 and $13.16 \%$, SAR by 17.23 and $8.92 \%$, ESP by 17.23 and $8.92 \%$ for site 1 and site 2, respectively as compared to the control. While, the sodium removal efficiency (RSE \%) with different treatments was increased in somewhat according to the following order: $\mathrm{G}+\mathrm{C}+\mathrm{B}_{2}>\mathrm{G}+\mathrm{C}+\mathrm{B}_{1}>\mathrm{G}+\mathrm{C}>\mathrm{G}+\mathrm{B}_{2}>\mathrm{G}+\mathrm{B}_{1}>\mathrm{G}>\mathrm{C}+\mathrm{B}_{2}>\mathrm{B}_{2}>\mathrm{C}+\mathrm{B}_{1}>\mathrm{C}>\mathrm{B}_{1}$ compared to that of the initial soil. Also, the application of different soil amendments decreased soil bulkdensity and increased soil porosity after the two growing seasons. The plant height, 1000-grain weight, grain yield and straw yields of wheat were significantly increased with different treatments.

Keywords: Soil amendments, Soil properties, Wheat productivity and Salt affected soils.

\section{INTRODUCTION}

Wheat is one of the most important cereal crops in Egypt and covers 1.32 million ha with an annual production of 8.45 million ton. Egypt's wheat consumption in 2018/19 at 20.1 ton, up 1.5 percent from the $2017 / 18$ estimate of 19.8 million tons. Egypt's wheat imports in 2018/19 at 12.5 ton, up 1.62 percent from the 2017/18 import figure of 12.3 million tons according to USDA (2018). So, the Egyptian government's, make efforts to increase the productivity of wheat per unit area by cultivating new soils and low water consumption (Mekkei and El Haggan, 2014).

Unfortunately, soil degradation resulting from soil salinity and/or sodicity, is a major problem of land resources under arid and semiarid climates (Qadir, et al 2007). Globally, about 95 million ha of soils are under primary salinization, while 77 million hectares are under secondary salinization (Metternicht and Zink, 2003; and Amini et al., 2016). In Egypt, nine hundred thousand ha of irrigated lands were salt affected soils (Abou-Baker and El-Dardiry, 2016). So, the salt affected soils are one of the available natural resources to increase the cultivation area in Egypt.

Amelioration of saline-sodic soil is becoming an increasingly vital tool to improve crop production by organic and inorganic amendments. Several studies have been carried out concerning the effectiveness of various amendments in improving the physical and chemical properties of saline sodic. One of these amendments gypsum $\left(\mathrm{CaSO}_{4}, 2 \mathrm{H}_{2} \mathrm{O}\right)$, is a naturally product that is mined for many purposes. Gypsum has a calcium content of $23 \%$. The application of gypsum reduced ECe, SAR and ESP (Shah et al., ,2013, Daur and Tatar, 2013, Amer ,2015, Hamad ,2015, Zia-Ur-Rehman et al., 2016, Amer ,2017, Kima et al., 2017, Saqib et al., 2017, Wafaa Hafez et al., ,2017, Ravinder et al., 2017 and Amer and Hashem, 2018), while the removal sodium efficiency calculated (RSE \%) significantly increased by 46.67, 57.89 and $71.83 \%$ in soil treated by gypsum, gypsum + sand, and gypsum + rice straw, respectively, compared to that of the initial soil (Amer,2017).

Biochar $(\mathrm{BC})$ is a $\mathrm{C}$ rich organic material which is produced by thermal decomposition of plant-derived biomass in partial or total absence of oxygen. The stability of $\mathrm{BC}$ in soil environment has been reported to be up to 1000 years (Sohi et al., 2010). Also, BC has been used in arable soils for improving soil physical properties and plant growth (Downie et al., 2009, Liu et al., 2014 and Lu et al., 2014). Biochar amendment decreased soil bulk density and increased soil porosity (Laird et al., 2010, Rachel et al., 2012, Jein and Wang, 2013, Aslam et al. ,2014, Njoku et al., 2015, Głąb et al., 2016 and Sara et al., 2018).

Compost tea is an infusion of compost in water for a period of time, the compost is removed, and the remaining solution is the compost tea, which is then applied to plant to provide beneficial microorganisms and essential plant nutrients (Scheuerell and Mahaffee 2004). Nasef et al., (2009) found that physical properties, ie. hydraulic conductivity, bulk density and total porosity of salt affected soil are greatly improved due application compost, compost tea and bio-fertilizer. Enshrah El-Maaz et al., (2016) found that soil EC and bulk density were decreased, while total porosity was increased due to application of compost tea. Amer (2016) concluded that soil EC, SAR and ESP and bulk density were decreased, while the soil porosity was increased with application of $400 \mathrm{~L}$ compost tea/fed.

This work aimed to study the improvement of some chemical and physical properties of salt affected clay soils to raise their productivity using some organic (compost tea and biochar) as well as inorganic (gypsum) amendments.

\section{MATERIALS AND METHODS}

\section{Experimental location and design:}

Two field experiments were conducted at two sites in Sakha Agric. Res. Station Farm, North Delta, during two successive winter seasons of 2017/18 and 2018/19 to study the effect of gypsum $(\mathrm{G})$, compost tea $(\mathrm{C})$ and biochar $(\mathrm{B})$ on some soil properties and wheat productivity under salt affected soils. The sitel is located at $31^{\circ} 05^{\prime} 26.4^{\prime \prime} \mathrm{N}$ latitude and $30^{\circ} 55^{\prime} 30.7^{\prime \prime} \mathrm{E}$ longitude, where the site 2 is located at $31^{\circ} 05^{\prime} 19.8^{\prime \prime} \mathrm{N}$ latitude and $30^{\circ} 56^{\prime} 13.2^{\prime \prime} \mathrm{E}$ longitude with an elevation of about 6 meters above the sea level.

The experiments were designed as complete randomized blocks design with three replicates. The treatments were: control, G (gypsum requirements) with a rate of 4.36 and $8.88 \mathrm{Mg} / \mathrm{fed}$ in sites 1 and 2 respectively $(\mathrm{Mg}=$ metric tons; $1 \mathrm{fed}=0.42 \mathrm{ha}), \mathrm{C}\left(400 \mathrm{~L} \mathrm{fed}^{-1}\right), \mathrm{B}_{1}\left(1.0 \mathrm{Mg} \mathrm{fed}^{-1}\right)$ and $B_{2}\left(2.0 \mathrm{Mg} \mathrm{fed}^{-1}\right)$ and their combinations; $\mathrm{G}+\mathrm{C}, \mathrm{G}+\mathrm{B}_{1}$, $\mathrm{G}+\mathrm{B}_{2}, \mathrm{C}+\mathrm{B}_{1}, \mathrm{C}+\mathrm{B}_{2}, \mathrm{G}+\mathrm{C}+\mathrm{B}_{1}$ and $\mathrm{G}+\mathrm{C}+\mathrm{B}_{2}$. Gypsum and biochar were thoroughly mixed with the surface soil layer (0$30 \mathrm{~cm}$ ) before cultivation, where the application of compost tea was blended with water of the $1^{\text {st }}$ and $2^{\text {nd }}$ irrigations.

\section{Cultural practices:}

The experimental sites were prepared and divided into plots $(2.5 \mathrm{~m} \mathrm{x} 2 \mathrm{~m})$. Gypsum requirements and biochar were ploughed with soil in the first season only. Gypsum 
requirements were determined according to (FAO and IIASA, 2000). These amounts are sufficient to reduce the initial ESP to $10 \%$ for the soil matrix in the surface layer according the following equation:

$$
\mathrm{Gr}=\left(\mathrm{ESP}_{\mathrm{i}}-\mathrm{ESP}_{\mathrm{F}}\right) / 100 \times \mathrm{CEC} \times 1.72
$$

Where Gr: gypsum requirement $\left(\mathrm{Mg} \mathrm{fed}^{-1}\right), \mathrm{ESP}_{\mathrm{i}}$ : initial soil ESP ESP: $_{f}$ The required soil ESP (10) and CEC: cation exchange capacity $\left(\mathrm{cmolc}^{\mathrm{kg}} \mathbf{}^{-1}\right)$.

To prepare the compost tea, $20 \mathrm{Kg}$ of maturing compost was soaked in 200 liters tap water. Then, the mixture was turned daily and filtrated after 10 days. The compost tea was enriched by Azospirillium spp with a rate of 2L/ $400 \mathrm{~L}$ of compost tea. Biochar is a fine-grained and porous substance and can be produced through the slow pyrolysis of feedstock at low-medium temperatures (i.e. 450$650^{\circ} \mathrm{C}$ ) in presence of limited oxygen source. The chemical composition of biochar and compost are listed in Table (1).

Table 1. Some chemical properties of the biochar and compost tea.

\begin{tabular}{|c|c|c|c|c|c|c|c|c|c|}
\hline \multirow{2}{*}{ Materials } & \multirow{2}{*}{$\begin{array}{l}\text { pH } \\
\text { (1: } \\
\text { 2.) }\end{array}$} & \multirow{2}{*}{$\begin{array}{l}\text { EC } \\
\text { (dS } \\
\left.\text { m }^{1}\right)\end{array}$} & \multicolumn{2}{|c|}{$\%$} & \multicolumn{5}{|c|}{$\left(\mathrm{mg} \mathrm{kg}^{-1}\right)$} \\
\hline & & & $\mathbf{N}$ & C & $\mathbf{P}$ & $\mathbf{K}$ & $\mathrm{Ca}$ & Mg & $\mathbf{N a}$ \\
\hline Biochar (B) & 7.9 & 2.05 & 1.22 & 66.7 & 22 & 984 & 52.4 & 22.4 & 0.3 \\
\hline Compost tea $(\mathrm{C})$ & 7.4 & 3.14 & 3.4 & 19.6 & 0.71 & 0.75 & 463 & 240 & 58 \\
\hline
\end{tabular}

Wheat (Triticum aestivum, L. Sakha 93) grains was sown at the rate of $60 \mathrm{~kg} /$ fed in the $1^{\text {st }}$ season on November $28^{\text {th }}, 2017$ and harvested after full maturity (April, 20 $0^{\text {th }}, 2017$ ). While in the $2^{\text {nd }}$ season it was sown on Nov., $19^{\text {th }}, 2018$ and harvested on April, $11^{\text {th }}, 2018$. Nitrogen fertilizer as urea $(46 \% \mathrm{~N})$ was applied at the rate of $75 \mathrm{~kg} \mathrm{~N}^{-1} \mathrm{fed}^{-1}$ in two doses, the first was following life watering irrigation and the second dose was done with second irrigation. Phosphorus was applied as a super mono phosphate with a rate of $31 \mathrm{~kg} \mathrm{P}_{2} \mathrm{O}_{5}$ $\mathrm{fed}^{-1}$, also100 $\mathrm{kg}$ potassium sulphate fed ${ }^{-1}\left(48 \% \mathrm{~K}_{2} \mathrm{O}\right)$ was applied with life watering. Other agricultural practices were performed according to the Ministry of Agriculture recommendation for wheat plants in North Delta area.

\section{Soil analysis:}

Surface soil samples $(0-30 \mathrm{~cm})$ were collected before and from each experimental unit at the end the experiment. Samples were air dried, crushed, sieved to pass through a $2.0 \mathrm{~mm}$ sieve and analyzed for their physical and chemical properties according to the standard methods outlined by Page et al. (1982) and Klute (1986). Sodium adsorption ratio (SAR) was calculated by the following equation according to (Richards, 1954): Where,

$$
\mathrm{SAR}=\mathrm{Na} \sqrt{ }\left(\mathrm{Ca}^{2+}+\mathrm{Mg}^{2+}\right) / \mathbf{2}
$$

While, Exchangeable sodium percentage (ESP) was calculated according to the equation of Rashidi and Seilsepour (2008):

$$
\mathrm{ESP}=1.95+1.03 \mathrm{SAR}
$$

Removal sodium efficiency (RSE) in percentage from soils at end of the experiment was calculated as follows equation Amer (2017):

$$
\mathrm{RSE}=\left(\mathrm{ESP}_{\mathrm{i}}-\mathrm{ESP}_{\mathrm{f}}\right) * 100 / \mathrm{ESP}_{\mathrm{i}}
$$

Where, ESP $_{i}$ is the initial ESP and ESP $_{f}$ is the final ESP at the end of the experiment.

Soil bulk density and total porosity in all plots were measured as described by (Klute, 1986 and Campbell, 1994). Organic matter content was determined according to Walkally \& Black method (Hesse, 1971). $\mathrm{CaCO}_{3}$ was determined using calcimeter meter method as described by (Piper, 1950). Cation exchange capacity (CEC) was determined using ammonium acetate method as described by (Rengasamy and Churchman, 1999). Mechanical analysis was determined according to the international pipette method (Dewis and Fertias, 1970). The soil content of available N was determined using $\mathrm{K}_{2} \mathrm{SO}_{4}(1 \%)$ according to Jackson (1973), Also, available $\mathrm{P}$ and $\mathrm{K}$ were extracted by ammonium bicarbonate- DTPA and determined according to Soltan pour (1985). Data of physical and chemical

\begin{tabular}{|c|c|c|c|c|c|c|c|c|c|c|c|c|c|c|c|}
\hline \multirow{2}{*}{ Sites } & \multirow{2}{*}{ pH } & \multirow{2}{*}{$\begin{array}{c}\text { EC } \\
d S / m\end{array}$} & \multicolumn{4}{|c|}{ Soluble cations meq / L } & \multicolumn{4}{|c|}{ Soluble anions meq / L } & \multirow{2}{*}{ SAR } & \multirow{2}{*}{ ESP } & AV & $\mathbf{A P}$ & AK \\
\hline & & & $\mathrm{Na}^{+}$ & $\mathbf{K}^{+}$ & $\mathrm{Ca}^{=}$ & $\mathrm{Mg}^{=}$ & $\mathrm{CO}_{3}{ }^{2}$ & $\mathrm{HCO}_{3}{ }^{-}$ & $\mathrm{Cl}^{-}$ & $\mathrm{SO}_{4}=$ & & & \multicolumn{3}{|c|}{$\mathrm{mg} / \mathrm{kg}$} \\
\hline & 8.23 & 6.81 & 46.3 & 0.2 & 15.0 & 6.1 & 0.0 & 4.0 & 36.1 & 27.5 & 14.25 & & 5. & 9.5 & 201 \\
\hline Site 2 & 8.52 & 14.8 & 100.6 & 0.3 & 32.6 & 13.3 & 0.0 & 2.5 & 78.5 & 65.8 & 21.01 & 23.59 & 50 & 8.2 & 185 \\
\hline
\end{tabular}
characteristics of the tested soil before planting are presented in Table (2-3).

Table 2. Soil chemical characteristics of the experimental site before cultivation.

\begin{tabular}{|c|c|c|c|c|c|c|c|c|c|}
\hline \multirow[b]{2}{*}{ Sites } & \multicolumn{4}{|c|}{ Soil mechanical analysis (\%) } & \multirow{2}{*}{$\underset{\%}{\text { OM }}$} & \multirow{2}{*}{$\begin{array}{c}\text { Total } \\
\mathrm{CaCO}_{3}(\%)\end{array}$} & \multirow{2}{*}{ 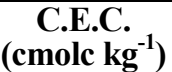 } & \multirow{2}{*}{$\begin{array}{l}\text { Bulk density } \\
\left(\mathrm{g} \mathrm{cm}^{-3}\right)\end{array}$} & \multirow{2}{*}{$\begin{array}{c}\text { Total porosity } \\
(\%)\end{array}$} \\
\hline & Sand & Silt & Clay & Texture & & & & & \\
\hline & 19.04 & 33.15 & 47.81 & Clay & 1.25 & 2.42 & 38.20 & 1.44 & 47.04 \\
\hline Site 2 & 18.5 & 31.41 & 50.09 & Clay & 1.16 & 2.31 & 37.97 & 1.43 & 45.66 \\
\hline
\end{tabular}

Soil pH in (1:2.5 soil: water suspension), whereas soil salinity (EC) in soil paste extract, AN, AP, AK are available N, P and K respectively.

Table 3. Some soil physical characteristics of the experimental site before cultivation.

Plant sampling:
At maturity stage, plant height $(\mathrm{cm})$ and 1000-grain weight $(\mathrm{g})$, total yield, grain and straw yield $\left(\mathrm{Mg} \mathrm{fed}^{-1}\right)$ were recorded for each plot.

\section{Statistical analyses:}

The obtained results were subjected to analyses of variance and LSD test at 0.05 and 0.01 levels of probability according to Gomez and Gomez (1984).

\section{RESULTS AND DISCUSSION}

I. Effect of different amendments on some soil chemical properties:

a. ECe:

The data in Figs (land 2) revealed that ECe values with different treatments were lower than that in the check plots. The lowest ECe values of saline-sodic soil in site 1 and site 2 were (4.43 and $13.08 \mathrm{dS} / \mathrm{m}$, respectively) were achieved due application of $\mathrm{G}+\mathrm{C}+\mathrm{B}_{2}$, while the check plots in both sites recorded the lowest ECe values (6.15 and 15.04 $\mathrm{dSm} 1$, respectively). Consequently, the decrease in ECe \% due to this combination treatment comparing to the control in both sites after the $2^{\text {nd }}$ season were $28.06 \%$ and $13.16 \%$, respectively (Table, 4$)$. Also, there were obvious differences in ECe values with various treatments comparing to the control. Also, ECe is indirectly related to the total concentration of soluble salts in soil and is a direct measurement of salinity. These results may attribute to the improvement in soil porosity and hydraulic conductivity as a result of soil amendments, which enhance the leaching of salts, as observed by Shah et al., (2013), Daur and Tatar 
(2013), Amer (2015), Hamad (2015), Zia-Ur-Rehman et al., (2016), Amer (2017), Kim et al., (2017), Saqib et al., (2017), Wafaa Hafez et al., (2017), Ravinder et al., (2017), Amer and Hashem (2018).

b. Soil alkalinity (SAR, ESP and RSE \%):

It was observed that the combined application of $\mathrm{G}+\mathrm{C}+\mathrm{B}_{2}$ was superior to all other treatments and clearly alleviated soil alkalinity since it reduced the values of SAR and ESP of soil after harvesting in the two growing seasons

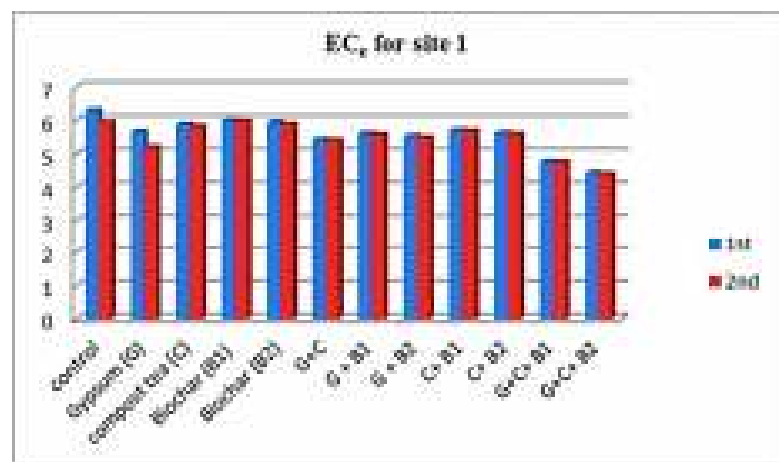

in both sites. This treatment exhibited the lowest values of SAR for site 1 and site 2 (11.19 and 19.29, respectively), while the highest values in both sites at the end of the experiment (13.52 and 21.18, respectively) were recorded in the control (Figs. 3 and 4). However, this combined treatment showed $17.23 \%$ and $8.92 \%$ decreases in SAR in both sites 1 and 2, respectively compared to the control at the end of the experiment (Table 4).

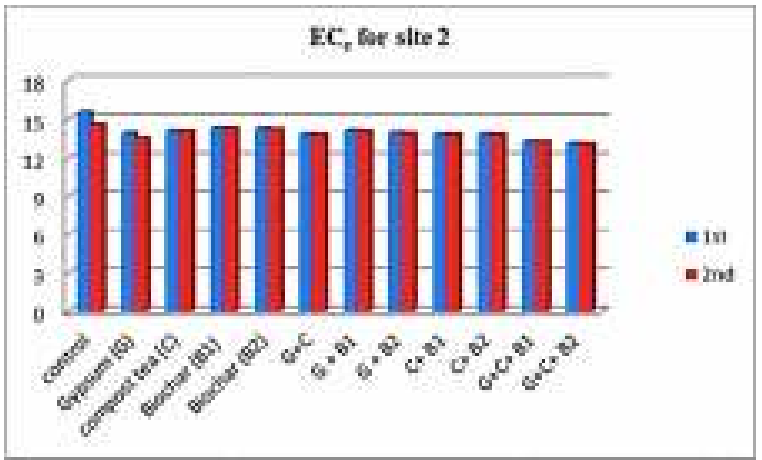

Figs. 1 and 2. Effect of organic and inorganic amendments on Electrical conductivity (ECe) of saturated soil extracts for site 1 and site 2 after two growing seasons.

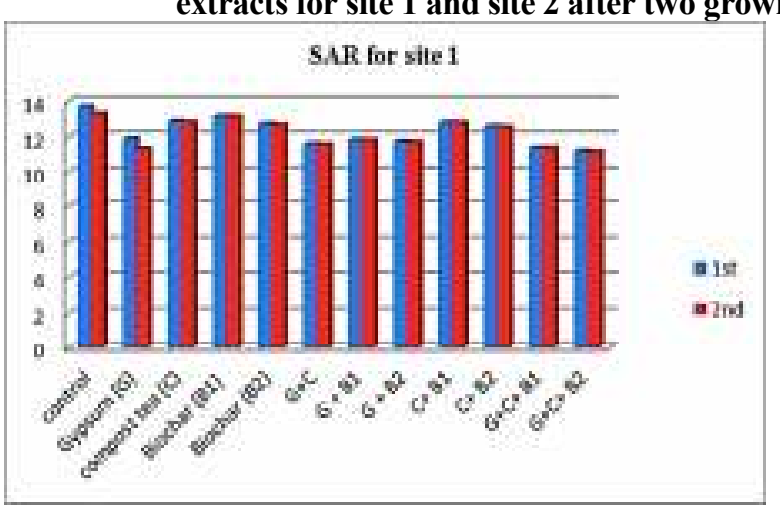
Figs. 3 and 4. Effect of organic and inorganic amendments
Also, the combination treatment of $\mathrm{G}+\mathrm{C}+\mathrm{B}_{2}$ achieved the lowest ESP values of soil in the $1^{\text {st }}$ and $2^{\text {nd }}$ sites (13.47 and 21.82, respectively) after the $2^{\text {nd }}$ season, while the check plots recorded the highest ESP values in both sites (15.88 and 23.77, respectively) after the $2^{\text {nd }}$ season (Figs.5 and 6). In addition, this combined treatment of added soil amendments showed $15.15 \%$ and $8.18 \%$ decreases in ESP in both sites, respectively compared to the control at the end of the experiment (Table 4).

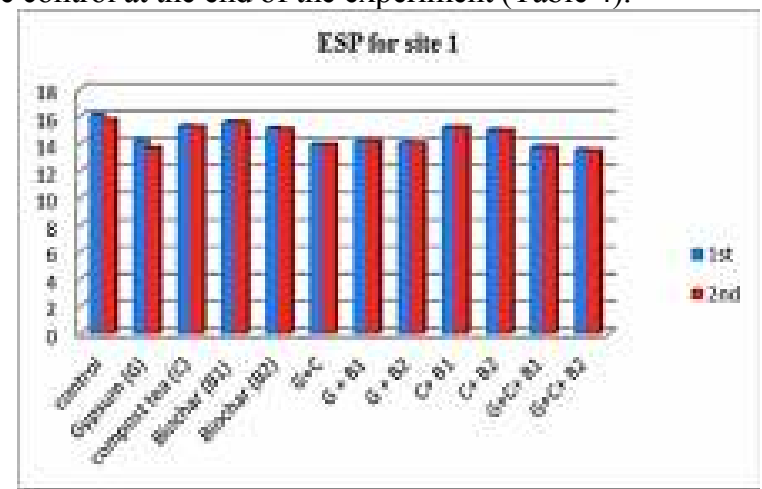

Figs. 5 and 6. Effect of organic and inorganic amendments

The removal sodium efficiency (RSE \%) clearly increased approximately according the following descending order: $\mathrm{G}+\mathrm{C}+\mathrm{B}_{2}>\mathrm{G}+\mathrm{C}+\mathrm{B}_{1}>\mathrm{G}+\mathrm{C}>\mathrm{G}+\mathrm{B}_{2}>$ $\mathrm{G}+\mathrm{B}_{1}>\mathrm{G}>\mathrm{C}+\mathrm{B}_{2}>\mathrm{B}_{2}>\mathrm{C}+\mathrm{B}_{1}>\mathrm{C}>\mathrm{B}_{1}$ compared to that of

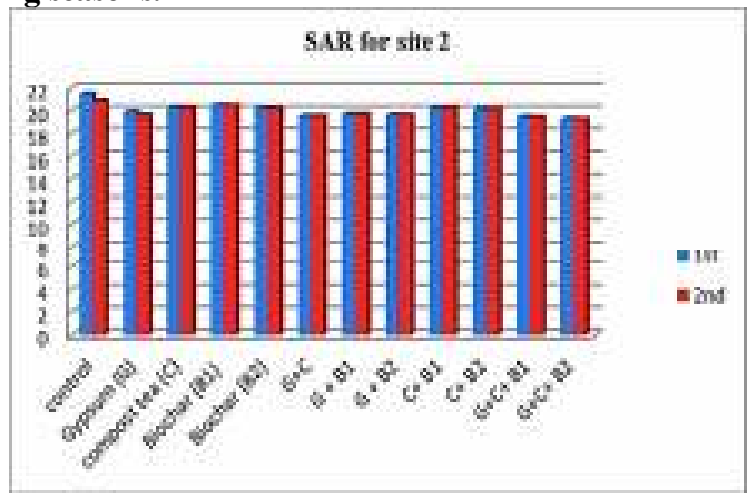

SAR of soil for site 1 and site 2 after two growing seasons.

The sodium adsorption ratio and exchangeable sodium percentage is reduced either due to increase of $\mathrm{Ca}$ on soil exchangeable complex as a result of the application of gypsum or due to the reactions of organic acids and compost tea with soil $\mathrm{CaCO}_{3}$. These results are in agreement with Amer (2017) and Amer and Hashem (2018) who reported that gypsum application decreasing SAR. Also, Amer (2016) concluded that compost tea and biochar decreased SAR.

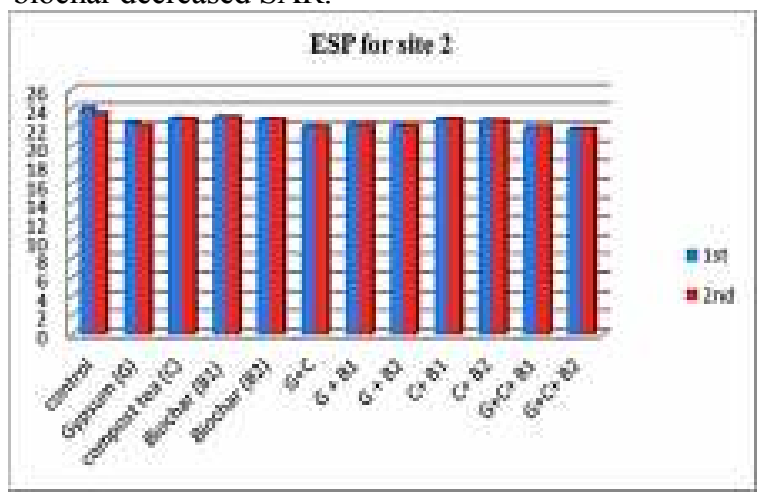

on EP soil for site 1 and site 2 after two growing seasons. the initial soil (Table 4). These results are in agreement with Amer (2017) who found that the RSE increased by $46.67,57.89$ and $71.83 \%$ in soil treated by G, G + sand and $\mathrm{G}+$ rice straw, respectively compared to the untreated soil. 
Table 4. Relative change ( $\pm \%$ ) in soil EC, SAR, ESP and RSE in surface layer as affected by different treatments of organic and inorganic amendments

\begin{tabular}{|c|c|c|c|c|c|c|c|}
\hline \multirow[b]{2}{*}{ Site } & \multirow[b]{2}{*}{ Amendments } & \multirow[b]{2}{*}{$\begin{array}{c}\text { EC } \\
( \pm \%)\end{array}$} & \multirow[b]{2}{*}{$\begin{array}{c}\text { SAR } \\
( \pm \%)\end{array}$} & \multirow[b]{2}{*}{$\begin{array}{c}\text { ESP } \\
( \pm \%)\end{array}$} & \multicolumn{3}{|c|}{ RSE \% } \\
\hline & & & & & $\begin{array}{c}1^{\text {st }} \\
\text { season }\end{array}$ & $\begin{array}{r}2^{\text {nd }} \\
\text { seaso }\end{array}$ & M \\
\hline & Control & 6.13 & 13.52 & 5.88 & & - & \\
\hline & Gypsum (G) & -11.26 & -13.94 & -12.22 & 11.44 & 13.02 & 12.23 \\
\hline & Compost tea (C) & -4.40 & -4.77 & -4.16 & 5.16 & 3.13 & 4.14 \\
\hline & Biochar $\left(\mathrm{B}_{1}\right)$ & -2.12 & -2.70 & -2.36 & 3.54 & 1.15 & 2.35 \\
\hline & Biochar $\left(\mathrm{B}_{2}\right)$ & -3.34 & -5.92 & -5.17 & 6.09 & 4.21 & 5.15 \\
\hline Site & $\mathrm{G}+\mathrm{C}$ & -11.42 & -14.02 & -12.28 & 13.31 & 11.23 & 12.27 \\
\hline \multirow[t]{13}{*}{1} & $\mathrm{G}+\mathrm{B}_{1}$ & -8.56 & -12.35 & -10.87 & 11.88 & 9.83 & 10.85 \\
\hline & $\mathrm{G}+\mathrm{B}_{2}$ & -9.95 & -13.17 & -11.53 & 12.50 & 10.53 & 11.51 \\
\hline & $\mathrm{C}+\mathrm{B}_{1}$ & -6.93 & -5.21 & -4.57 & 5.72 & 3.38 & 4.55 \\
\hline & $\mathrm{C}+\mathrm{B}_{2}$ & -8.40 & -6.88 & -6.02 & 7.09 & 4.91 & 6.00 \\
\hline & $\mathrm{G}+\mathrm{C}+\mathrm{B}_{1}$ & -22.27 & -15.61 & -13.67 & 14.74 & 12.57 & 13.66 \\
\hline & $\mathrm{G}+\mathrm{C}+\mathrm{B}_{2}$ & -27.81 & -17.23 & -15.15 & 16.11 & 14.17 & 15.14 \\
\hline & Contrc & 15.04 & 21.18 & 23.77 & 0.0 & 0.0 & 0.0 \\
\hline & Gypsum (G) & -8.84 & -6.63 & -6.08 & 6.76 & 5.38 & 6.07 \\
\hline & compost tea $(\mathrm{C})$ & -6.62 & -4.06 & -3.72 & 5.02 & 2.39 & 3.70 \\
\hline & Biochar $\left(\mathrm{B}_{1}\right)$ & -4.95 & -3.19 & -2.92 & 4.27 & 1.54 & 2.90 \\
\hline & $\operatorname{Biochar}\left(\mathrm{B}_{2}\right)$ & -5.39 & -4.44 & -4.06 & 5.31 & 2.78 & 4.04 \\
\hline & $\mathrm{G}+\mathrm{C}$ & -8.34 & -7.79 & -7.15 & 8.42 & 5.85 & 7.13 \\
\hline & $\mathrm{G}+\mathrm{B}_{1}$ & -6.52 & -6.82 & -6.23 & 7.51 & 4.91 & 6.21 \\
\hline Site & $\mathrm{G}+\mathrm{B}_{2}$ & -7.55 & -7.37 & -6.75 & 8.00 & 5.47 & 6.74 \\
\hline \multirow[t]{4}{*}{2} & $\mathrm{C}+\mathrm{B}_{1}$ & -8.28 & -4.23 & -3.87 & 5.23 & 2.48 & 3.85 \\
\hline & $\mathrm{C}+\mathrm{B}_{2}$ & -8.24 & -4.89 & -4.50 & 5.81 & 3.16 & 4.48 \\
\hline & $\mathrm{G}+\mathrm{C}+\mathrm{B}_{1}$ & -12.13 & -8.05 & -7.38 & 8.71 & 6.02 & 7.37 \\
\hline & $\mathrm{G}+\mathrm{C}+\mathrm{B}_{2}$ & -13.07 & -8.92 & -8.18 & 9.46 & 6.87 & 8.17 \\
\hline
\end{tabular}

II. Effect of different amendments on soil bulk density and total porosity:

Results in Table (5) revealed that, the lowest values of soil bulk density (1.33 and $1.34 \mathrm{Mg} / \mathrm{m}^{3}$ respectively) and the highest values of porosity ( 48.65 and $47.12 \%$, respectively) were obtained by application of $\mathrm{G}+\mathrm{C}+\mathrm{B}_{2}$ in both sites, respectively as a mean of both growing seasons. These results may be attributed to the role of biochar application in increasing of soil porosity through (i) pore contribution due to high-porosity of biochar, and (ii) improved aggregate stability (Hardie et al., 2014). Also, addition of gypsum led to a reduction in soil bulk density and a corresponding increase in soil porosity (Amer, 2015, Kim et al., 2017, Ravinder et al., 2017 and Amer and Hashem , 2018). In addition, compost tea caused reduction in soil bulk density and an increase in soil porosity (Scheuerell and Mahaffee, 2004, Nasef et al., 2009, Enshrah and Fatma, 2016 and Amer .2016).

III. Effect of organic and inorganic amendments on plant height, yield and yield components:

Figs 7, 8,9 and 10 argued that application of G, C or $\mathrm{B}$ individually or combined strongly affected the plant

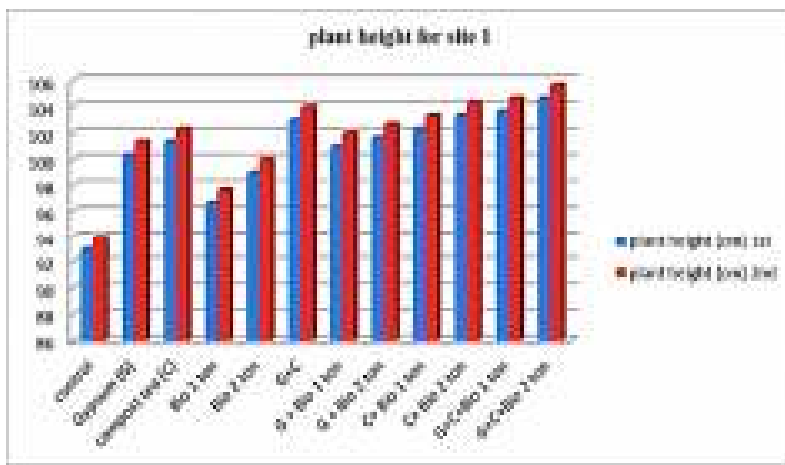

heights and 1000-grain weight of wheat. The plots amended by $\mathrm{G}+\mathrm{C}+\mathrm{B}_{2}$ in both sites achieved the tallest plants and the heaviest grains, while the lowest values of both parameters were recorded with the untreated plants.

Table 5. Soil bulk density (BD) and porosity and their relative change $( \pm \%)$ as affected by organic and inorganic amendments.

\begin{tabular}{|c|c|c|c|c|c|c|c|}
\hline \multirow[b]{2}{*}{ Site } & \multirow[b]{2}{*}{ Amendments } & \multicolumn{2}{|c|}{$\begin{array}{c}\text { Bd } \\
\left(\mathrm{Mg} \mathrm{m}^{-3}\right)\end{array}$} & \multirow[b]{2}{*}{ 出 } & \multicolumn{2}{|c|}{$\begin{array}{c}\text { Total } \\
\text { porosity \% }\end{array}$} & \multirow{2}{*}{$\begin{array}{l}\stackrel{e}{0} \\
\stackrel{0}{0} \\
\stackrel{0}{0}\end{array}$} \\
\hline & & 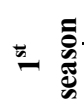 & 兄 & & 七 & స̆ & \\
\hline \multirow{12}{*}{$\begin{array}{l}\text { Site } \\
1\end{array}$} & Control & 1.44 & 1.45 & 1.45 & 47.04 & 47.07 & 47.06 \\
\hline & Gypsum (G) & 1.41 & 1.42 & -2.42 & 47.83 & 47.86 & +1.65 \\
\hline & compost tea (C) & 1.37 & 1.38 & -5.19 & 47.33 & 47.36 & +0.58 \\
\hline & Biochar $\left(\mathrm{B}_{1}\right)$ & 1.38 & 1.39 & -4.50 & 47.35 & 47.38 & +0.63 \\
\hline & Biochar $\left(\mathrm{B}_{2}\right)$ & 1.35 & 1.36 & -6.57 & 47.53 & 47.56 & +1.01 \\
\hline & $\mathrm{G}+\mathrm{C}$ & 1.39 & 1.40 & -3.81 & 48.05 & 48.08 & +2.11 \\
\hline & $\mathrm{G}+\mathrm{B}_{1}$ & 1.40 & 1.41 & -3.11 & 48.11 & 48.14 & +2.24 \\
\hline & $\mathrm{G}+\mathrm{B}_{2}$ & 1.38 & 1.39 & -4.50 & 48.26 & 48.29 & +2.56 \\
\hline & $\mathrm{C}+\mathrm{B}_{1}$ & 1.38 & 1.39 & -4.50 & 47.60 & 47.63 & +1.16 \\
\hline & $\mathrm{C}+\mathrm{B}_{2}$ & 1.36 & 1.37 & -5.88 & 47.68 & 47.71 & +1.33 \\
\hline & $\mathrm{G}+\mathrm{C}+\mathrm{B}_{1}$ & 1.33 & 1.34 & -7.96 & 48.26 & 48.29 & +2.56 \\
\hline & $\mathrm{G}+\mathrm{C}+\mathrm{B}_{2}$ & 1.32 & 1.33 & -8.65 & 48.64 & 48.67 & +3.37 \\
\hline \multirow{12}{*}{$\begin{array}{l}\text { Site } \\
2\end{array}$} & Control & 1.43 & 1.44 & 1.44 & 45.66 & 45.71 & 45.69 \\
\hline & Gypsum (G) & 1.41 & 1.42 & -1.74 & 46.37 & 46.42 & +1.50 \\
\hline & compost tea (C) & 1.36 & 1.37 & -5.23 & 45.86 & 45.91 & +0.38 \\
\hline & Biochar $\left(\mathrm{B}_{1}\right)$ & 1.38 & 1.39 & -3.83 & 45.97 & 46.02 & +0.62 \\
\hline & Biochar $\left(B_{2}\right)$ & 1.34 & 1.35 & -6.62 & 46.07 & 46.12 & +0.84 \\
\hline & $\mathrm{G}+\mathrm{C}$ & 1.39 & 1.40 & -3.14 & 46.59 & 46.64 & +1.98 \\
\hline & $\mathrm{G}+\mathrm{B}_{1}$ & 1.39 & 1.40 & -3.14 & 46.56 & 46.61 & +1.92 \\
\hline & $\mathrm{G}+\mathrm{B}_{2}$ & 1.40 & 1.41 & -2.44 & 46.75 & 46.80 & +2.33 \\
\hline & $\mathrm{C}+\mathrm{B}_{1}$ & 1.39 & 1.40 & -3.14 & 46.04 & 46.09 & +0.78 \\
\hline & $\mathrm{C}+\mathrm{B}_{2}$ & 1.37 & 1.38 & -4.53 & 46.25 & 46.30 & +1.24 \\
\hline & $\mathrm{G}+\mathrm{C}+\mathrm{B}_{1}$ & 1.34 & 1.35 & -6.62 & 46.80 & 46.85 & +2.44 \\
\hline & $\mathrm{G}+\mathrm{C}+\mathrm{B}_{2}$ & 1.33 & 1.34 & -7.32 & 47.10 & 47.15 & +3.10 \\
\hline
\end{tabular}

On the other side, the data in Table (6) revealed that the grain and straw yields were significantly increased by different amendments in both growing seasons. The plots amended by $\mathrm{G}+\mathrm{C}+\mathrm{B}_{2}$ in both sites seemed to produce the highest grain yields (3.017 and 2.282 ton/fed, respectively) with relative increase of 37.3 and $56.0 \%$, respectively and the highest straw yields (4.137 and 3.171 ton/fed, respectively), with increase of 22.4 and $31.3 \%$, respectively compared to the control. However, this combined treatment in both sites showed 37.3 and $56.0 \%$, increases in grain yield respectively, while with the increases in straw yield were 22.4 and $31.3 \%$, respectively comparing to the control which recorded the lowest yields of grain (2198 1.463 ton/fed, respectively) and straw (3381and 2.415 ton/fed, respectively).

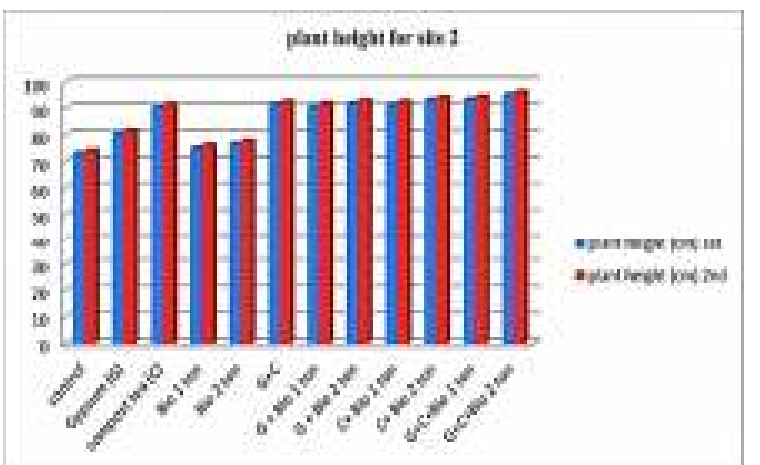

Figs. 7 and 8. Effect of organic and inorganic amendments on plant height of wheat plant for a- site 1 and b- site 2 after two growing seasons. 

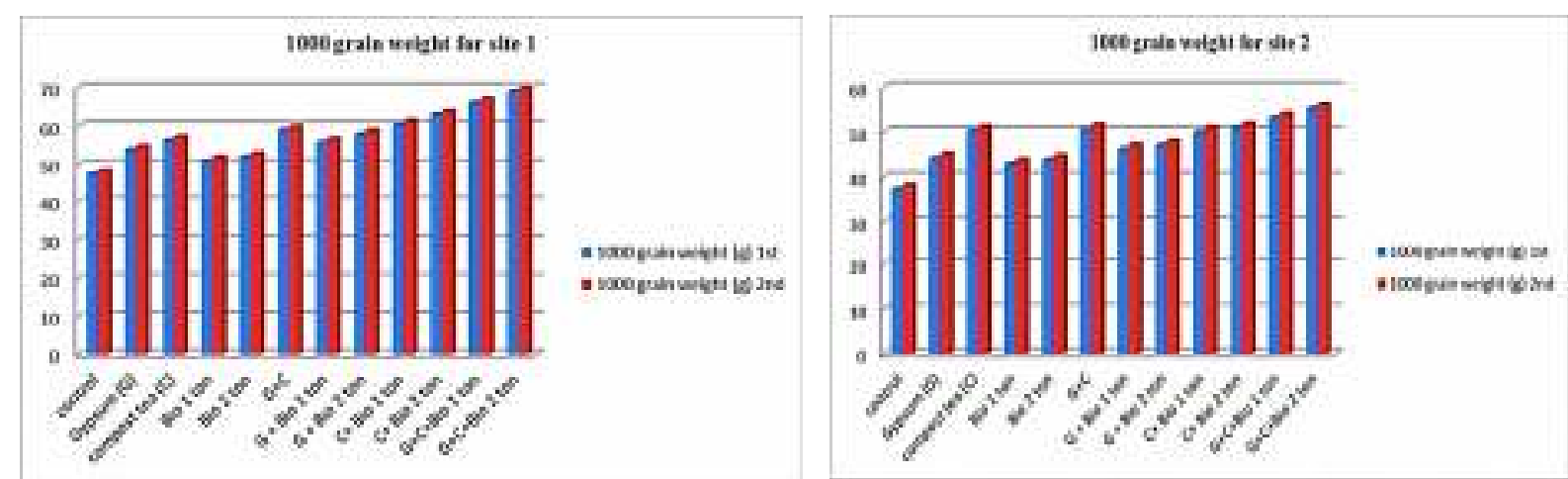

Figs. 9 and 10. Effect of the amendments on 1000-grain weight for a- site 1 and b- site 2 after two growing seasons.

The ameliorative role of the previous amendments in salt affected soils may be attributed to the increase the tolerance of plants to salinity at physiological growth stages and improve some soil proprieties. Similar results were obtained by Shah et al., (2013), Zia-Ur-Rehman et al., (2016), Saqib et al., (2017) and Amer (2017) who found that application of $\mathrm{G}$ increased plant heights, 1000- grain weight, grain yield and straw yield of wheat, and Amer (2016) who observed that application of B and C or significantly increased the yield of wheat and maize. Also, Iqbal (2017) reported that plant height, thousand grain weight, grain yield and straw yield of wheat were increased with addition of biochar.

Table 6. Mean value of grain and straw yield of wheat as affected by organic and inorganic amendments

\begin{tabular}{|c|c|c|c|c|c|c|c|}
\hline \multirow[b]{2}{*}{ Site } & \multirow[b]{2}{*}{ Amendments } & \multicolumn{2}{|c|}{ 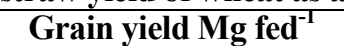 } & \multirow{2}{*}{$\begin{array}{c}\text { Relative } \\
\text { G.Y. }( \pm \%)\end{array}$} & \multicolumn{2}{|c|}{ Straw yield Mg fed ${ }^{-}$} & \multirow{2}{*}{$\begin{array}{c}\text { Relative } \\
\text { S.Y. }( \pm \%) \text {. }\end{array}$} \\
\hline & & $1^{\text {st }}$ season & $2^{\text {nd }}$ season & & $1^{\text {st }}$ season & $2^{\text {nd }}$ season & \\
\hline \multirow{19}{*}{ Site 1} & Control & 2072 & 2324 & 0.0 & 3318 & 3444 & 3381.00 \\
\hline & Gypsum (G) & 2478 & 2730 & +18.47 & 3689 & 3815 & +10.97 \\
\hline & compost tea $(\mathrm{C})$ & 2583 & 2835 & +23.25 & 3647 & 3773 & +9.73 \\
\hline & $\operatorname{Biochar}\left(\mathrm{B}_{1}\right)$ & 2331 & 2583 & +11.78 & 3411 & 3437 & +1.27 \\
\hline & Biochar $\left(\mathrm{B}_{2}\right)$ & 2436 & 2688 & +16.56 & 3731 & 3857 & +12.22 \\
\hline & $\mathrm{G}+\mathrm{C}$ & 2772 & 3024 & +31.85 & 3696 & 3822 & +11.18 \\
\hline & $\mathrm{G}+\mathrm{B}_{1}$ & 2569 & 2821 & +22.61 & 3514 & 3640 & +5.80 \\
\hline & $\mathrm{G}+\mathrm{B}_{2}$ & 2667 & 2919 & +27.07 & 3640 & 3766 & +9.52 \\
\hline & $\mathrm{C}+\mathrm{B}_{1}$ & 2590 & 2842 & +23.57 & 3727 & 3853 & +12.09 \\
\hline & $\mathrm{C}+\mathrm{B}_{2}$ & 2653 & 2905 & +26.43 & 3913 & 4039 & +17.60 \\
\hline & $\mathrm{G}+\mathrm{C}+\mathrm{B}_{1}$ & 2835 & 3087 & +34.71 & 3955 & 4081 & +18.84 \\
\hline & $\mathrm{G}+\mathrm{C}+\mathrm{B}_{2}$ & 2891 & 3143 & +37.26 & 4074 & 4200 & +22.36 \\
\hline & G F- test & ** & ** & & ns & ns & \\
\hline & C F- test & $* *$ & ** & & $*$ & * & \\
\hline & B F- test & $* *$ & $* *$ & & $* *$ & $* *$ & \\
\hline & $\mathrm{G}^{*} \mathrm{C}$ F- test & $* *$ & $* *$ & & $* *$ & $* *$ & \\
\hline & $\mathrm{G}^{*} \mathrm{~B}$ F- test & $* *$ & $* *$ & & $* *$ & $* *$ & \\
\hline & $\mathrm{C}^{*} \mathrm{~B}$ F- test & ** & $* *$ & & ns & ns & \\
\hline & $\mathrm{G}^{*} \mathrm{C} * \mathrm{~B}$ F- test & ** & ** & & ** & ** & \\
\hline \multirow{19}{*}{ Site 2} & Control & 1337 & 1589 & 1463.00 & 2352 & 2478 & 2415.00 \\
\hline & Gypsum (G) & 1743 & 1995 & +27.75 & 2723 & 2849 & +15.36 \\
\hline & compost tea $(\mathrm{C})$ & 1848 & 2100 & +34.93 & 2681 & 2807 & +13.62 \\
\hline & $\operatorname{Biochar}\left(\mathrm{B}_{1}\right)$ & 1596 & 1848 & +17.70 & 2465 & 2491 & +2.61 \\
\hline & Biochar $\left(\mathrm{B}_{2}\right)$ & 1701 & 1953 & +24.88 & 2765 & 2891 & +17.10 \\
\hline & $\mathrm{G}+\mathrm{C}$ & 2037 & 2289 & +47.85 & 2730 & 2856 & +15.65 \\
\hline & $\mathrm{G}+\mathrm{B}_{1}$ & 1834 & 2086 & +33.97 & 2548 & 2674 & +8.12 \\
\hline & $\mathrm{G}+\mathrm{B}_{2}$ & 1932 & 2184 & +40.67 & 2674 & 2800 & +13.33 \\
\hline & $\mathrm{C}+\mathrm{B}_{1}$ & 1855 & 2107 & +35.41 & 2761 & 2887 & +16.93 \\
\hline & $\mathrm{C}+\mathrm{B}_{2}$ & 1932 & 2184 & +40.67 & 2933 & 3059 & +24.06 \\
\hline & $\mathrm{G}+\mathrm{C}+\mathrm{B}_{1}$ & 2100 & 2352 & +52.15 & 2989 & 3115 & +26.38 \\
\hline & $\mathrm{G}+\mathrm{C}+\mathrm{B}_{2}$ & 2156 & 2408 & +55.98 & 3108 & 3234 & +31.30 \\
\hline & G F- test & $* *$ & ** & & ns & ns & \\
\hline & C F- test & $* *$ & ** & & * & * & \\
\hline & B F- test & $* *$ & $* *$ & & $* *$ & $* *$ & \\
\hline & $\mathrm{G}^{*} \mathrm{C}$ F- test & $* *$ & ** & & ** & ** & \\
\hline & $\mathrm{G}^{*} \mathrm{~B}$ F- test & $* *$ & $* *$ & & $* *$ & $* *$ & \\
\hline & C*B F- test & $* *$ & ** & & ns & ns & \\
\hline & $\mathrm{G}^{*} \mathrm{C}^{*} \mathrm{~B}$ F- test & ** & ** & & ** & ** & \\
\hline
\end{tabular}

\section{CONCLUSION}

The results showed that organic and inorganic amendments can improve saline-sodic soils properties and positively affected wheat growth and yield. Thus, it can be concluded that application of gypsum + compost tea + biochar can be used to combat salt effects on plant growth and improve wheat productivity and soil properties under saline-sodic soil conditions. 


\section{REFERENCES}

Abou-Baker, N., and E. El-Dardiry, (2016). Integrated management of salt affected soils in agriculture: Incorporation of soil salinity control methods. Academic Press, Elsevier, London.

Amer, A. Kh. (2017). Role of soil amendments, plant growth regulators and amino acids in improvement salt affected soils properties and wheat productivity. J.Soil Sci. and Agric. Eng., Mansoura Univ., 8 (3):123-131.

Amer, M. M. (2015). Effect of gypsum, sugar factory lime and molas on some soil proprieties and productivity of sugar beet (Beta Vulgaris L.) grown on salinesodic soils of Nile North Delta. J.Soil Sci. and Agric. Eng., Mansoura Univ., Vol. 6 (3): 385 - 401.

Amer M. M. (2016). Effect of biochar, compost tea and magnetic iron ore application on some Soil Properties and Productivity of Some Field Crops under Saline Soils Conditions at North Nile Delta . Egypt. J. Soil Sci. 56 (1).169-186.

Amer M. M. and I. M. Hashem (2018). Impact of some soil amendments on properties and productivity of salt affected soils at Kafr El-Sheikh Governorate. Egypt. J. Soil Sci., 58 (2): 177-191.

Amini S., H. Ghadiri, C. Chen and P. Marschner (2016). Salt-affected soils, reclamation, carbon dynamics, and biochar: a review. Journal of Soils and Sediments, 16(3), 939-953.

Aslam Z., M. Khalid and M. Aon (2014). Impact of Biochar on Soil Physical Properties. Scholarly J. Agric. Sci. 4(5). 280-284

Campbell, D.J. (1994) Determination and use of bulk density in relation to soil compaction. In Soane and Ouwerk (Ed.). Soil Compaction in Crop Production. Elsevere, London, Amsterdam.

Daur I. and Ö. Tatar (2013). Effects of gypsum And brassinolide on soil Properties, and Berseem (Trifolium alexandrinum L.) growth, yield and chemical composition grown on saline soil. Legume Res., 36 (4): $306-311$.

Dewis, J. and F. Fertias, (1970)." Physical and chemical methods of soil and water analysis": Soil Bulletin No.10 FAO .Rome.

Downie A., A. Crosky, and P. Munroe (2009). Physical properties of biochar. Biochar for environmental management: science and technology. Eds Lehmann, J and Joseph, S. Earthscan, London, 1332.

Enshrah I. M. El-Maaz and Ismail S.H. Fatma (2016). Impact of bio-fertilizer, humic acid and compost Tea applications on Soil Properties and egyptian Clover productivity under saline soil conditions. J.Soil Sci. and Agric. Eng., Mansoura Univ., 7 (9):611-622.

FAO and IIASA (2000) Diagnosis and improvement of saline and alkali sols, USDA Handbook No 60, U.S. Salinity Lab. Staff (1954), Washington.

Głąba T., J. Palmowskaa, T. Zaleskib, K. Gondekc (2016). Effect of biochar application on soil hydrological properties and physical quality of sandy soil. Geoderma 281:11-20.
Gohar, A. T. (1954). The influence of Exchangeaple cations on Physical Properties of Egyptian Soil M. Sci. Thesis, Fac. of Agric. Cairo Univ.

Gomez, K.A. and, A.A. Gomez, (1984) Statistical Procedures for Agric. Res., 2nd edition. John Wiley and Sons, New York, 680.

Hamad .M.M.H. (2015). Comparative study between different soil amendments for improving some soil properties and wheat productivity In saline sodic soil. J.Soil Sci. and Agric. Eng., Mansoura Univ. 6 (8): 1001- 1015.

Hardie, M., B. Clothier, S. Bound, G. Oliver, and D. Close (2014). Does biochar influence soil physical properties and soil water availability. Plant Soil 376 (1-2), 347-361.

Hesse, P. R. (1971). A Text book of Soil Chemical Analysis. John Murray Ltd, London, pp. 520.

Iqbal M. T. (2017) Utilization of biochar in improving yield of wheat in Bangladesh. Bulgarian Journal of Soil Science. 2. (1). 53:74.

Jackson, M. L. (1973). "Soil chemical analysis." 2nd Ed. Prentice hall of India Private and L. T. D., New Delhi, India.

Jien S.H, and C.S. Wang (2013). Effects of biochar on soil properties and erosion potential in a highly weathered soil. Catena 110: $225-233$.

Kima, Y. J., B. K. Choob, and J.Y. Choc, (2017). Effect of gypsum and rice straw compost application on improvements of soil quality during desalination of reclaimed coastal tideland soils: Ten years of longterm experiments. Catena 156: 131-138.

Klute, A. Ed. (1986). "Methods of soil analysis". No. 9 Part 1, Amer. Soc. Agron., Inc. Madison, Wisconsin, USA.

Laird, D.A.; P. Fleming; D.D. Davis; R. Horton; B. Wang and D.L. Karlen, (2010). Impact of biochar amendments on the quality of a typical midwestern agricultural soil. Geoderma, 158, 443-449.

Liu, Z., X. Chen, and Y. Jing (2014). Effects of biochar amendment on rapeseed and sweet potato yields and water stable aggregate in upland red soil. Catena 123, 45-51.

Lu, S.G., F.-F. Sun, and Y.T. Zong, (2014). Effect of rice husk biochar and coal fly ash on some physical properties of expansive clayey soil (vertisol). Catena 114, 37-44.

Mekkei M.E. and A.M. El Haggan, (2014). Effect of different irrigation regimes on grain yield and quality of some egyptian bread wheat cultivars. JAAS. J., 2 (9) 275-282.

Metternicht G., and J. Zink. (2003). Remote sensing of soil salinity: potentials and constraints. Remote Sensing of Environment, 85: 1-20.

Nasef, M. A.; KH. A. Shaban, and A. F. Abd El- Hamide, (2009). Effect of compost, compost tea and biofertilizer application on some chemical soil properties and rice productivity under saline soil condition. J. Agric. Mansoura Univ. 34 (4): 26092623. 
Njoku, C.,C.N. Mbah, P.O., Igboji, J.N, Nwite, C.C,Chibuike, and B.N.Uguru, (2015). Effect of biochar on selected soil physical properties and maize yield in an ultisol in abakaliki southeastern Nigeria. Glo. Adv. Res. J. Agric. Sci. (ISSN: 23155094) Vol. 4(12) :864-870.

Page, A.L., R. H. Miller and D.R. Keeney (1982). Methods of Soil Analysis". Part 2: Chemical and microbiological properties. second edition, Amer Soc. Of Agron. Madison, Wisconsin, USA.

Piper, C.S. (1950). Soil and Plant Analysis. Inter science Publication. New York.

Qadir M., J. D. Oster, S. Schubert, A. D. Noble, and K. L.Sahrawat (2007). Phytoremediation of sodic and saline-sodic soils. Advances in Agronomy, 96, 197247.

Rachel C. Devereux, Craig J. Sturrock and S J. Mooney (2012). The effects of biochar on soil physical properties and winter wheat growth. Earth and Environmental Science Transactions of the Royal Society of Edinburgh, 103: 13-18.

Rashidi M. and M. Seilsepour, (2008). Modeling of soil exchangeable sodium percentage based on soil sodium adsorption ratio. Arpn Journal of Agricultural and Biological Science. 3 (4) July Issn 1990-6145.

Ravinder J., N. M. Konde and V. K. Kharche (2017). Effect of organic amendments and gypsum on physico chemical properties of salt affected purna valley soils and cotton yield in vidarbha region. Int.J.Curr.Microbiol.App.Sci. 6 (9): 3741-3747.

Rengasamy P, Churchman GJ (1999). Cation Exchange Capacity, Exchangeable Cations and Sodicity. In Soil Analysis an Interpretation Manual. (Eds KI Peverill, LA Sparrow and DJ Reuter). CSIRO: Melbourne.

Richards L.A. (1954). Diagnosis and improvement of saline and alkali soils. USDA Agricultural Handbook No. 60, US Department of Agriculture, Washington DC. 160 p.
Saqib A.I., K. Ahmed, G. Qadir, M.Q. Nawaz, M. Rizwan, M.A. Zaka, I. A. Warraich (2017). An organic and inorganic amendments for rehabilitation of salt affected soils. Cercetări Agronomice In Moldova Vol. L, 1 (169): 19-29

Sara; Z. Shah and T. Shah (2018). Residual Effect of biochar on soil properties and yield of maize (Zea mays L.) under different Cropping Systems. Open J. of Soil Sci., 8: 16-35.

Scheuerell, S.J. and W.F. Mahaffee (2004). Compost tea as a container medium drench for suppressing seedling damping-off caused by Pultimum. Phytopathol.. 94 (11), 1156-1163.

Shah Z., I. ul Haq, A. Rehman, A. Khan and M. Afzal (2013). Soil amendments and seed priming influence nutrients uptake, soil properties, yield and yield components of wheat (Triticum aestivum L.) in alkali soils. Soil Science and Plant Nutrition, 59: 262- 270

Sohi, S.P., E., Krull, E., Lopez-Capel, and Bol, R., (2010). A review of biochar and its use and function in soil. Adv. Agron., 105: 47-82.

Soltan pour, N. (1985). Use of ammonium bicarbonateDTPA soil test to evaluate elemental availability and toxicity. Soil Sci. Plant Anal., 16 (3): 323- 338.

USDA (2018). Wheat and Corn Imports Hold Steady Despite Increased Local Production. GAIN Report Number: EG18020. Required Report - public distribution. Date: 9/9/2018

Wafaa A. Hafez; Zeinab M. Abd El-Naby; Walaa M. E. Mousa and Hend H. M. Hassan (2017). Impact of Some Soil Amendments Application on Soil Properties, Fodder Beet Productivity and Quality under Salt Affected Soil. J.Soil Sci. and Agric. Eng., Mansoura Univ., 8 (11): 605-612.

Zia-Ur-Rehman M., M. Rizwan, M. Sabir, Shahjahan, S. Ali and H. R. Ahmed (2016). Comparative effects of different soil conditioners on wheat growth and yield grown in saline-sodic soils. Sains Malaysiana 45 (3): 339-346.

\section{تأثير بعض المحسنات العضوية والغير عضوية علي بعض خواص التربة وانتاجية القمح تحت ظروف التربة المتأثرة

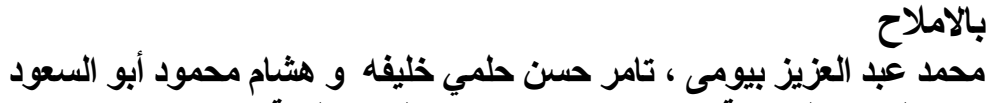 مركز البحوث الزراعية ـ معهد بحوث الاراضى دئ والمياه والبيئة}

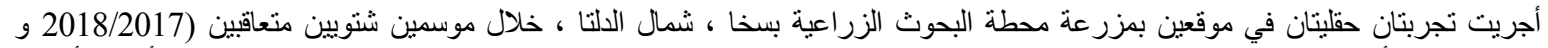

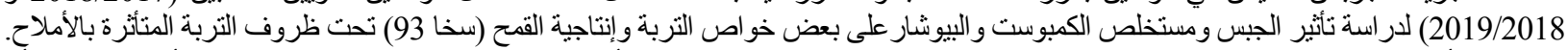

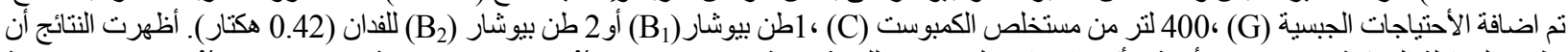

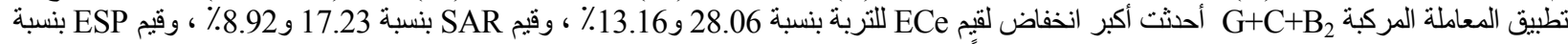

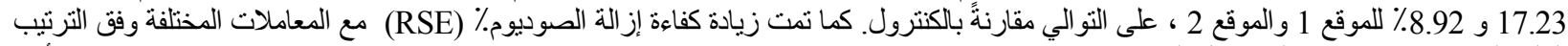
التالي إلى حد ما مقارنة مع التربة قبل التجربة:

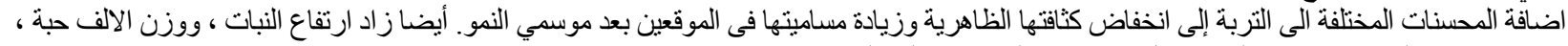
و إنتاجية محصولى حبوب وقثى القمح بشكل واضح مع المعاملات المختلفة. 